\title{
Ilan Pappé
}

\section{From Balfour to the Nakba}

\section{The Settler Colonial Experience of Palestine}

This article examines the Balfour Declaration (1917) from the perspective of the settler colonial paradigm. The Declaration was possible due to the settler colonial nature of Zionism which resonated not only with British strategists who preferred a Jewish to an Arab colony in Palestine, but also with Christian Zionists such as David Lloyd George who believed that the "the return of the Jews" was God's will and part of a divine scheme. This British support, which until 1948 is one of the major causes of the Palestinian Nakba (the Catastrophe).

\section{Zionism and settler colonialism}

The prominent scholar of settler colonialism, Patrick Wolfe (19462016) reminded us repeatedly that settler colonialism is not an event, it's a structure. By that he meant that although settler colonialism in many cases has a historical starting point, its original motivation still guides its maintenance in the present. Settler colonial projects, by and large, were motivated by what Wolfe defined as "the logic of the elimination of the native." ${ }^{1}$ This logic guided settler colonial projects when they encountered native populations in foreign countries. The European settlers chose places for their new safe homelands that were already inhabited by other people. The logic of annihilation dictated that the only way of safeguarding these new homelands was by getting rid of the indigenous population.

The settlers' wish to create a new home, indeed a new homeland, clashed almost inevitably with the aspirations of the local native Palestinian population. In some cases, the "logic of the elimination of the native", (as the main response to this clash) indeed ended in physical 
elimination of the native - as can be seen from the genocides of the native Americans in North, Central and South America and that of the Aboriginals in Australia. In other cases, the clash was solved by other means. In South Africa, for instance, the settlers enclaved the indigenous population in closed areas and later imposed an apartheid system on them.

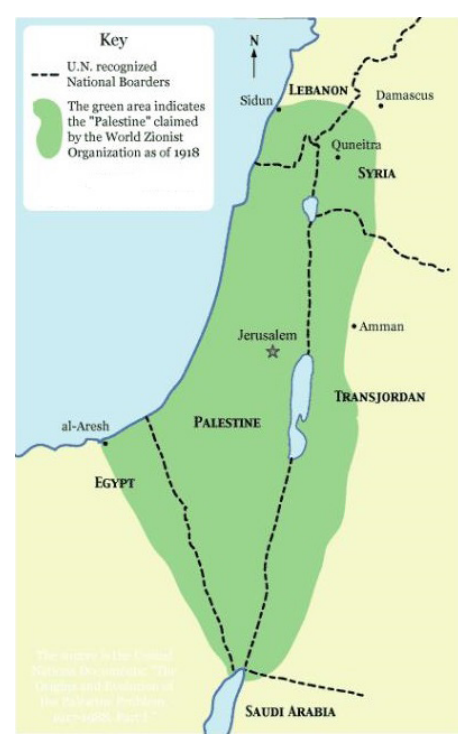

There was another common feature to settler colonial movements - the European settlers in general needed the help of an empire for the initial colonisation, but developed later their own agenda and collective identity that led them to rebel against that very empire. This led to historical moments such as the American Revolution in 1776 and the Boer Wars in South Africa in the late 19th century. In the case of Zionism, the British army and imperial power helped to protect the Jewish settlers from 1918 until 1948; without such support the Palestinian and general Arab rejection of the Zionist project would have destroyed it. After the Second World War, the Zionist movement felt strong enough Image 1. s.n. Areas claimed in to stand on its own feet and commenced 'Palestine' by the World Zionist a campaign to end the British rule in Organisation as of 1918.

Palestine. Britain at that time still wished to retain its control over Palestineand therefore a clash between the two sides was inevitable. The Zionist struggle included acts of terrorism, the most famous was the blowing up of the British headquarters in the King David Hotel in Jerusalem in 1946, which cost the lives of many innocent people.

The principal premise of this article is that Zionism in Palestine is a settler colonial project and Israel is still today a settler colonial state. ${ }^{2}$ This depiction is now widely accepted in the scholarly world, but still rejected by mainstream Israeli scholars. It's from this perspective that I would like to revisit the Balfour Declaration and ponder upon its significance today. On November 2, 1917, Arthur Balfour (1848-1930), the British Foreign Secretary, sent a letter to Baron Lionel de Rothschild (1868-1937), who was the nominal head of the Anglo-Jewish community. As an active Zionist and close friend of Chaim Weizmann, he worked to formulate the draft 
declaration for a Jewish homeland in Palestine. Weizmann, who was born in Russia and gained local fame in Britain for his scientific chemistry work at the University of Manchester which contributed to the British war effort in the First World War.

In the letter from Balfour to Rothschild the British government declared its support for the establishment in Palestine of "a national home for the Jewish people" and promising to do this without "prejudicing" the "civil and religious rights" of the "non-Jewish communities in Palestine".

From reading this letter it seems as if the Jews were the native and majority population of Palestine, living beside small non-Jewish groups. The demographic, cultural and political reality in Palestine at the time shows that it was in fact very different. The vast majority of the people living in Palestine were Muslim and there was a sizable Christian community. The Jews all together formed ten percent of the population and quite a few of them regarded themselves as Arabs and not as part of a new Jewish nation in $1917 .^{3}$

The declaration also contradicted the Sykes-Picot agreement (May, 1916) in which Britain promised France to rule Palestine jointly as an international enclave and the correspondence between the British High Commissioner in Egypt, Sir Henry McMahon and the Sharif Hussein of Mecca, that included Palestine in the area promised to the Sharif and his sons as part of their future kingdom. ${ }^{4}$

This misrepresentation of the Palestine reality in the Balfour Declaration is the first indication of how applicable the settler colonial paradigm is to the case of the Zionist movement in Palestine. The settler movement obtained the support of a colonial and imperial power, one which it would disown from 1942 onwards. It shared with the Empire a perception of the local population as at best a tolerated minority and at worst as usurpers who took over a land that had belonged to the settlers. The imperial power, in this case Britain, granted the international legitimacy for this act of colonisation, sowing the seeds for future dispossession of the native population.

\section{The Origins of the Declaration}

Most historians explain the Balfour Declaration in terms of British strategic thinking. It was part of an Islamophobic attempt to prevent a Muslim Holy Land as well as an apprehension that some other European powers might support Zionism. The Israeli scholar Mayer Verete, whose 1970-article on 
the Declaration is still one of the best (probably since most of the historical material was already available to him at the time that he wrote the article), highlighted also the misconception British policy makers had about the possible power Jews had both in the Bolshevik movement and the United States. The British policy makers asserted wrongly that the support for Zionism would satisfy these two Jewish communities and turn them into potential British allies in the future (Bolshevism had nothing do with Zionism and it took a while before American Jewry became a factor in American policy towards Palestine). ${ }^{5}$

What Verete missed can be complimented by applying the settler colonial paradigm to his and others' more recent comprehensive analyses of the origins of the Balfour Declaration. British support for establishing a Jewish homeland in Palestine had its roots in an evangelical Christian Zionist dogma mushrooming on both sides of the Atlantic already in the early nineteenth century. Long before the Balfour Declaration, Christian settler colonialism penetrated North America and Africa, deeming these two continents as the new Zion and the Holy Land. These projects, like Zionism, relied first on British imperialism and then rebelled against it. More importantly, the British variety of Christian Zionism focused more closely on the religious significance of a Jewish "return" to Palestine. This "return" in ecclesiastical terms was a precursor for the resurrection of the dead and the second coming of the Messiah. These millenarian ideologies were taken seriously and influenced important British politicians at the time of the Balfour Declaration, among them the Prime Minister at the time, David Lloyd George. ${ }^{6}$

Even before that, in the mid-nineteenth century, British consuls on the ground in Palestine, such as James Finn, associated this end of time scenario not only with the return of Jesus but also with the conversion of Jews to Christianity (otherwise they would roast in Hell). Finn opened an office in Jerusalem for the conversion of Jews to Christianity and helped Jews to immigrate to Palestine long before the first Zionist settler arrived there. ${ }^{7}$

Thus, the settler colonial paradigm highlights the theological connection between Christianity in Britain and Zionism in the nineteenth and twentieth centuries, and its relationship with the settler colonial project supported by Britain in other parts of the world.

These obvious and less obvious connections became even clearer in the years that followed the Balfour Declaration. At the time, the letter was not considered to be of immense importance as it was part of a series of vague 
imperial commitments meant to secure contemporary alliances and not future geopolitical arrangements. It became a crucial factor in the history of Israel and Palestine when it was integrated into the mandatory charter which the League of Nations granted Britain over Palestine. Moreover, its importance was enhanced by the appointment of Herbert Samuel (18701963), a pro-Zionist Anglo-Jew as the first High Commissioner of Palestine. Immediately upon his arrival to Palestine in 1920, Samuel put in place policies that allowed the settler colonial movement to bring in more settlers and to expand its foothold in the country by purchasing land mainly from absentee landlords.

The Palestinian national movement was organized enough to resist popular and violent means against the settler colonial project in Palestine. In the early years, the vulnerable Jewish colony was strongly protected by the British army. The British were particularly important during the most significant Palestinian attempt to shake off pro-Zionist British influence in 1936. For three years, Palestinian guerrillas waged a revolt against this policy. It was brutally crushed with all the might the British Empire could muster. This resulted in the destruction of the Palestinian military and political elite: many of its members were either killed, wounded or expelled. This left the Palestinian society defenceless and leaderless when both were needed most in $1948 .^{8}$

\section{The Balfour Declaration and the Nakba}

There is a direct line connecting the vague British promise given to the Zionist movement one hundred years ago and the catastrophe that befell the Palestinian people in 1948 (almost seventy years ago). A few British policy makers must have had doubts about the Balfour Declaration and therefore questioned its validity. For example in 1930, they even considered the repudiation of the Balfour Declaration but retracted quickly from such a dramatic U-turn. In 1939, British policy makers tried to restrict Jewish immigration and purchase of land, but were castigated later for this policy due to the rise of Nazism and Fascism which turned Palestine to one of the few safe havens for Jews escaping from Europe. The condemnation, one should say, came from a hypocritical western world that did very little to save the Jews during the Holocaust or open its gates to its survivors immediately after the war. The British had to accept an inter- 
national verdict in which the Jews of Europe would be compensated by allowing the Zionist movement to further colonise Palestine. ${ }^{9}$ They also became the enemies of the Zionist movement, as happened in the case of the American and South African settlers respectively; the Zionists began its war of independence against the British Empire.

These pressures, together with the transformation of Britain from a world power to a second grade actor on the international scene, led to their decision in February 1947 to pass the question of Palestine on to the United Nations. Britain was still responsible for law and order between February 1947 to May 1948. Within this responsibility it witnessed, remained indifferent, and, at times, even was an accomplice to the final and disastrous outcome of the Balfour Declaration: the 1948 ethnic cleansing of the Palestinians. ${ }^{10}$

The British decision prompted the military and political leadership of the Jewish community to devise their own version of "the logic of the elimination of the native". While conducting an effective diplomatic effort to obtain international legitimacy for the idea of a Jewish State (even at the price, as transpired later on, that such legitimacy would be granted to only part of Palestine), this leadership contemplated also the removal of the Palestinian community from any part which would form the future Jewish State. It was in the beginning of March 1948 that this strategy produced Plan D, or Plan Dalet. In mine and that of many other historians' (perhaps controversial) opinion, this was a clear blueprint for the systematic removal of the Palestinians from Palestine. ${ }^{11}$ The Plan itself, a document of several pages, was less important by itself, it's significance lay in the way it was translated into a set of operative commands that were despatched to the Jewish forces in March, April and May 1948. The essence of these orders was to occupy villages, towns and neighbourhoods, expel their people and, in the case of the villages, detonate the houses so as to prevent any return to them. ${ }^{12}$

The British were already retreating from some parts of Palestine when this ethnic cleansing commenced. However, they were present in Palestinian urban areas and it was there that the main ethnic cleansing effort took place. They were present when most Palestinians were expelled from Haifa, Jaffa and Acre, all together more than 100,000 people. They watched, mediated in order to facilitate the transfer (as in the case of Haifa), but did not intervene when the people, who began to leave under an agreement, were shelled by the Jewish forces while leaving to the harbour. This was a 
shameful chapter that even some British politicians at the time recognized, but the British government in general did not show much regret. It was as shameful as the Declaration itself. When the ethnic cleansing ended, half of Palestine's population was expelled, half of its villages were demolished and most of its towns were depopulated. On their ruins Israel built Kibbutzim, "development towns" (new towns built around one factory usually for new immigrants who came after 1948) and planted European pine trees to try and erase the Arab nature of Palestine. ${ }^{13}$

Britain recognised quite quickly the Jewish state and contributed further to the Palestinian disaster by supporting the partition of post-mandate Palestine between Jordan and Israel. The Israeli-Jordanian understanding about this arrangement was concluded before the 1948 war and implemented with the help of the senior officers of the Jordanian army - all of them British officers. This was a non-written understanding which accorded to Jordan, without a fight, the West Bank. In return, the Jordanian army, the best trained and most effective in the Arab world, played only a limited role in the 1948 fighting.

The British government in London was fully aware of this understanding and supported it. Moreover, the British did all they could to prevent the making of a Palestinian state in even part of Palestine. They called such a state a Mufti State, namely one which would be ruled by the Grand Mufti of Jerusalem whom they accused of collaborating with the Nazis in the Second World War. Thus, the creating of a greater Jordan, by adding 20 percent of Palestine to Jordan and recognising the Jewish state, stretching over 78 percent of the country ( 2 percent was the Egyptian controlled Gaza Strip), completed the ruination of Palestine which became the inevitable consequence of the Balfour Declaration. ${ }^{14}$

However, the settler colonial project of Zionism has not been as successful as the American or the Australian one and may still have a similar ending to the one in South Africa. It is too early to tell, but what is clear is that through this prism one can understand better why there is a conflict in Israel and Palestine and what at least in principle should be the way forward for solving it. 


\section{Noten}

1. Patrick Wolfe, "Settler Colonialism and the Elimination of the Native", Journal of Genocide Research 8, no. 4 (December 2006): 387-409.

2. Lorenzo Veracini, Israel and Settler Society (London: Pluto, 2006).

3. Salim Tamari, "Ishaq al-Shami and the Predicament of the Arab-Jew in Palestine", The Jerusalem Quarterly 21 (2004): 10-26.

4. There is a debate going on even today whether in these letters Britain promised Palestine to the Arabs (represented in this case by the Sharif Hussein of Mecca see: Charles D. Smith, "The Invention of a Tradition: The Question of Arab Acceptance of the Zionist Right to Palestine during World War I," Journal of Palestine Studies, Volume 22, No. 2 (Winter, 1993), pp. 48-61.

5. Mayer Verete, "The Balfour Declaration and Its Makers", Middle Eastern Studies 6, issue 1 (1970): 48-76.

6. I have dealt with these developments in Ilan Pappe, The Ten Myths of Israel (London and New York: Verso, 2016), 11-23.

7. Falesten Naili, "The Millennialist Settlement in Artas and its Support Network in Britain and North America, 1845-1878," The Jerusalem Quarterly 45 (2011): 43-56.

8. This thesis is convincingly put forward by Tom Segev, One Palestine, Complete (New York: Picador, 2001), 426-427.

9. See discussion of how this worked in Ilan Pappe, The Making of the Arab Israeli Conflict, 1948-1951 (London and New York: I.B Tauris, 1992), pp. 16-46.

10. I have analysed this British policy in Ilan Pappe, Britain and the Arab Israeli Conflict, 1947-1951 (London and New York: I.B Tauris 2010), pp. 87-102.

11. The debate is covered in Ilan Pappe, "Were They Expelled?: The History, Historiography and Relevance of the Refugee Problem" in The Palestinian Exodus, 19: 148-1988, Ghada Karmi and Eugene Cortan (eds.) (London: Ithaca, 1999): 37-62.

12. See Ilan Pappe, The Ethnic Cleansing of Palestine (Oxford and New York: Oneworld, 2007), 86-123.

13. I have described and analysed in Pappe, the Ethnic Cleansing, ibid, pp. 225-229.

14. Avi Shlaim, Collusion Across the Jordan (New York: Columbia University Press, 1988), pp. 80-107. 